3612

日本機械学会論文集 (C 編)

論文 No. 10-0217

76 巻 772 号 $(2010-12)$

\title{
過渡応答を考慮した入力拘束システムの目標信号追従制御*
}

\author{
和田 信 敬*1, 南昌 行*2 \\ 佐 伯 正 美*3, 西 村 正 治*4
}

\section{Tracking Control of Input Constrained Discrete-Time Systems Considering Transient Response}

\author{
Nobutaka WADA*5, Masayuki MINAMI, \\ Masami SAEKI and Masaharu NISHIMURA \\ ${ }^{* 5}$ Department of Mechanical and Aerospace Engineering, Tottori University, \\ 4-101 Koyama-Minami, Tottori-shi, Tottori, 680-8552 Japan
}

\begin{abstract}
In this paper, a tracking control problem in the presence of actuator saturation is addressed. Firstly, a control law that guarantees both closed-loop stability and asymptotic convergence of the tracking error in the case of a constant reference signal is introduced. The feedback gain of the control law is adjusted, at each sampling time, so that both large region of attraction and fast convergence of the tracking error are achieved. Secondly, based on the control law, a control algorithm that can be used for arbitrary time-varying reference signals is proposed. The most important feature of the proposed control algorithm is that the overshoot of the plant output can be effectively attenuated. Moreover, the effectiveness of the proposed control algorithm is shown through experimental results.
\end{abstract}

Key Words : Gain-Scheduling, Reference Management, On-line Optimization, Constraint

\section{1.は じめ に}

現実の機械システムで用いられているアクチュエー タには，最大出力や変化率，稼動範囲等に制約が存在 する.これらの制約を無視してフィードバック制御系を 設計すると，急激な目標值変更や過大な外乱が加わっ た際に，アクチュエータ出力が制約を越え，閉ループ 系の不安定化や装置の破壊などが生じる場合がある ${ }^{(1)}$. このような問題は，搭載するアクチュエータに厳しい 重量制限のある，移動体の制御系において特に生じや すい(2).この問題に対処する方法の一つに，想定され るあらゆる目標信号や外乱が加わった場合にも，アク チュエータが制限を破らないように，ローゲインの制 御器を設計する方法が挙げられる: この方法で設計し た制御器を用いると, 目標入力の振幅が小さい場合に は，小さな制御入力しか用いることが出来ず，制御性 能は保守的なものとなる。一方，ハイゲインな制御器 を用いると，目標入力が小さい場合には高い制御性能 を達成できるが，大きな目標入力が加わった際にアク

* 原稿受付 2010 年 3 月 25 日.

*1 正員, 鳥取大学大学院工学研究科機械宇宙工学専攻 (画 6808552 鳥取市湖山町南 4-101).

*2 広島大学大学院工学研究科機械システム工学専攻 (画 7398527 東広島市鏡山 1-4-1).

*3 正員, 広島大学大学院工学研究科機械システム工学専攻.

*4 正員, フェロー, 鳥取大学大学院工学研究科機械宇宙工学専 攻.

E-mail : nwada@mech.tottori-u.ac.jp
チュエータ出力が制限を越え易くなり，閉ループ系が 不安定化する可能性が生じる.

この問題に対し，近年の急速な計算機パワーの増大 を背景として，実時間最適化に基づく新たな制御器の 構成法が示されている(3) (5) ，その一つに，状態依存 可変ゲイン制御がある ${ }^{(5)}$. 状態依存可変ゲイン制御で は, 状態空間の原点近傍でハイゲイン，原点から遠ざ かるに従い滑らかにローダインとなる制御器を設計 しておき，毎時刻，出来るだけ高い制御性能が得られ るようにゲインの更新が行われる.この方法を用いる と，広い漸近安定領域と原点近傍での高い制御性能を 両立させることが可能となる.この手法は，目標信号 追従制御問題に対して拡張され ${ }^{(6)}$ ，実機によりその有 効性が検証されている(7). しかしながら、この手法で は，制御量が目標値に漸近的に追従することが理論的 に保証されるのみであり，過渡応答については特に考 慮されていない，そのため，特に制御器が積分特性を 有する場合に，オーバーシュートがしばしば発生する といった問題が生じていた.

そこで, 本稿では, 文献 ${ }^{(6)}$ の制御アルゴリズムを改 良し，過渡的なオーバーシュートの発生を抑制する新 たな目標信号追従制御アルゴリズムを提案する.さら 
に，提案制御アルゴリズムの有効性を，数值例，並び に，実機実験によって検証した結果を示す．実機実験 では, ツインローダーヘリコプターモデル(8)を制御対 象として用いた。この実験装置は, 多入力・非線形系 であることから一般に制御困難な対象であると言える. また，不安定系であることから，ある程度短いサンプ 儿周期で制御を実行する必要があり，実時間最適化が 要求される提案制御手法の実用性を検証するのに適し ていると言える. 本稿では，この実験装置に対して， ローターの推力制限の下で，上下方向および姿勢を安 定化し，かつ，横方向の速度を目標信号に素早く追従 させる飛行制御器を設計し, その有効性を実験的に検 証する。

記号: ベクトル $u \in \mathcal{R}^{m}$ について, 多変数飽和関数 を $\Phi(u):=\left(\phi\left(u_{1}\right), \cdots, \phi\left(u_{m}\right)\right)^{T}$ で定義する. ただし， $\phi\left(u_{i}\right):=\operatorname{sgn}\left(u_{i}\right) \min \left\{\left|u_{i}\right|, 1\right\}$ である. $v \in \mathcal{R}^{n}$ につい て，そのユークリッドノルムを $\|v\|_{2}:=\left(v^{T} v\right)^{1 / 2}$ で 表す. 正定対称行列 $P \in \mathcal{R}^{n \times n}$ について，楕円集合 $\mathcal{E}(P, \eta):=\left\{x \in \mathcal{R}^{n}: x^{T} P x \leq \eta\right\}$ を定義する. 行列 $F \in \mathcal{R}^{m \times n}$ の第 $i$ 行を $F^{(i)}$ と表す. $\mathcal{V}$ は, 要素が 1 か $0 の m \times m$ 次対角行列の集合を表す. 明らかに，Vは $2^{m}$ の要素を持つ. $\mathcal{V}$ の各要素を $\mathrm{E}_{j}, j=1,2, \cdots, 2^{m}$ と表す.また， $\mathbf{E}_{j}^{-}:=I-\mathbf{E}_{j}$ を定義する.

\section{2. 問 題 設 定}

以下のシステムについて考える.

$$
\begin{aligned}
x(t+1) & =A x(t)+B \Phi(u(t))+E w(t) \\
z(t) & =C x(t)+D \Phi(u(t))+D_{w} w(t)
\end{aligned}
$$

ただし $, x \in \mathcal{R}^{n}, u \in \mathcal{R}^{m}, w \in \mathcal{R}^{p}, z \in \mathcal{R}^{q}$ である. $w(t)$ は外部信号である。 また， $z(t)$ は追従誤差を表す (例えば, 制御量が $y(t)=C_{y} x(t)$ で与えられている場 合, 追従誤差は $z(t)=w(t)-y(t)$ となる). なお, 式 (1), (2) の係数行列の具体的な選び方については, 第 4 節の数值例，および, 第 5 節の実験例を参照された い. 本稿では，以下の制御問題について考える.

問題 1 システム (1), (2) および以下の制御器

$$
\begin{aligned}
u(t) & =F(t) x(t)+M(t) w(t) \\
w(t) & =\mathbb{K}(r(t), x(t))
\end{aligned}
$$

から構成される制御系（図 1 参照）について考える. ここで, $r \in \mathcal{R}^{p}$ は目標信号である.この制御系につ いて，1）目標信号 $r(t)$ が零である場合には広い漸近 安定領域を達成し，2）目標信号 $r(t)$ がある時刻以降 一定值 $\bar{r}$ となる場合には $w(t) \rightarrow \bar{r},(t \rightarrow \infty)$ および $z(t) \rightarrow 0,(t \rightarrow \infty)$ を達成し, さらに，3）目標信号

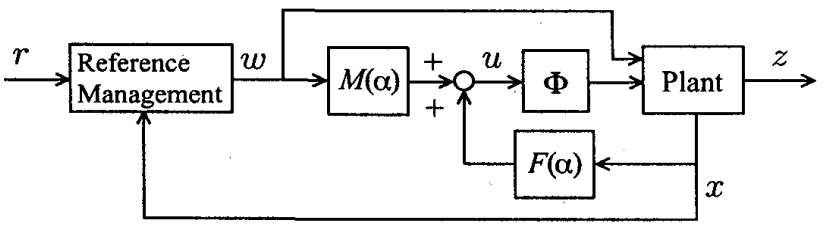

Fig. 1 Control system with a reference management device

$r(t)$ が時変信号である場合には追従誤差 $z(t)$ を毎時刻 出来るだけ小さな值とする制御器 (3), (4)の具体的構 成法を示せ.

本稿では, 式 (3) をフィードバック制御則, 式 (4) を目標信号修正機構と呼ぶことに守る，文献 ${ }^{(6)}$ では， 可変ゲイン制御手法 ${ }^{(5)}$ に基づく式 (3) の設計法，およ び, 正不変集合の連続的移動による式 (4)の一構成法 を示した. 本稿では,フィードバック制御則の設計は, 文献 ${ }^{(6)}$ の結果に基づき行うことにする.そこで，第 3 節では，まず，文献 ${ }^{(6)}$ の制御器設計法を紹介する。 ぎに，オーバーシュートの発生を抑制する新たな制御 アルゴリズムを提案する.

\section{3. 過渡応答を考慮した追従制御}

3.1 制御器設計 はじめに, 可変ゲイン制御器 設計に用いる定理を示す。

定理 $1^{(6)}$ システム (1), (2)について考える. ただし, 次式を満たす $\Pi \in \mathcal{R}^{n \times p}, \Gamma \in \mathcal{R}^{m \times p}$ が存在するもの とする。

$$
\begin{aligned}
\Pi & =A \Pi+B \Gamma+E \\
0 & =C \Pi+D \Gamma+D_{w}
\end{aligned}
$$

また, $w(t)$ はステップ信号 $w(t)=\bar{w}, \forall t \geq 0$ であ り, $\left|\Gamma^{(l)} \bar{w}\right|<1, \forall l \in[1, m]$ の関係を満たすものとす る.さらに，ある正定数 $\eta, \gamma_{0}, \gamma_{1}$ （ただし $\gamma_{0}<\gamma_{1}$ ） および行列 $\mathbf{R}>0, \mathbf{S}>0$ について, 次式を満たす行 列 $Q_{i}, Y_{i}, Z_{i},(i=0,1)$ が存在するものとする.

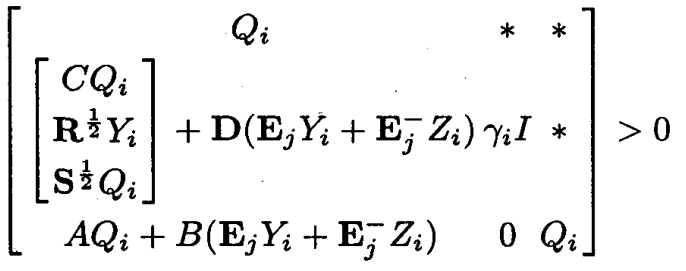

$$
\begin{aligned}
& \forall i \in[0,1], \forall j \in\left[1,2^{m}\right] \quad(7) \\
& \begin{array}{l}
{\left[\begin{array}{cc}
Q_{i} & * \\
Z_{i}^{(l)} & \frac{\rho_{l}^{2}}{\eta}
\end{array}\right] \geq 0, \quad \forall i \in[0,1], \forall l \in[1, m]} \\
Q_{0}<Q_{1}
\end{array}
\end{aligned}
$$

ただし $, \rho_{l}:=1-\left|\Gamma^{(l)} \bar{w}\right|, \mathbf{D}:=\left[D^{T}, 0,0\right]^{T}$ で あり，*は行列不等式の対称な要素を表す。ささらに， 


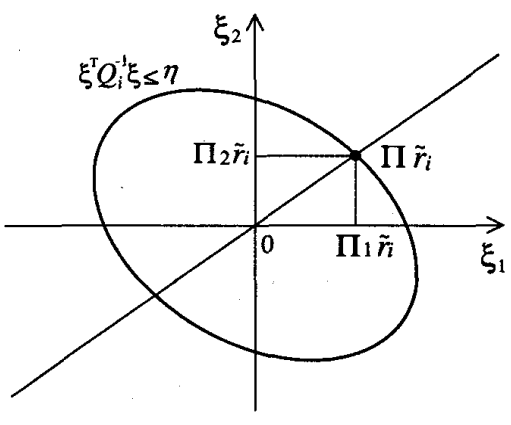

Fig. $2 \tilde{r}_{i}$

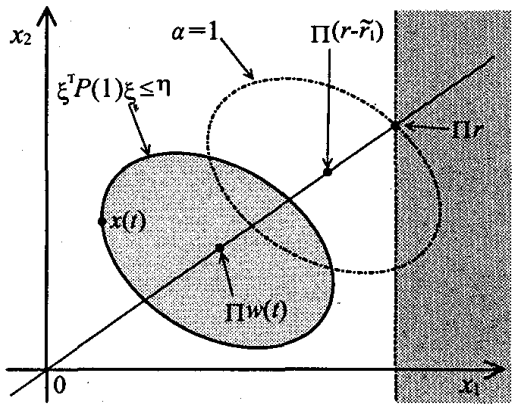

Fig. 3 Step 4 of Algorithm 1

$\xi(0) \in \mathcal{E}(P(\alpha), \eta)$ を満たす定数 $\alpha \in[0,1]$ が存在す るものとする. ただし, $P(\alpha):=Q(\alpha)^{-1}, Q(\alpha):=$ $(1-\alpha) Q_{0}+\alpha Q_{1}, \xi:=x-\Pi w$ である. このとき, フィードバック制御則

$$
u(t)=F(\alpha) x(t)+M(\alpha) w(t)
$$

をシステム (1), (2) に適用すると, $\xi(t) \in$ $\mathcal{E}(P(\alpha), \eta), \forall t \geq 0$ および $\lim _{t \rightarrow \infty} z(t)=0$ の関 係が成り立つ.ただし, $F(\alpha)=Y(\alpha) Q(\alpha)^{-1}$, $Y(\alpha):=(1-\alpha) Y_{0}+\alpha Y_{1}$ であり, $M(\alpha)=\Gamma-F(\alpha) \Pi$ である.また， $J:=\sum_{t=0}^{\infty}\|\mathbf{z}(t)\|_{2}^{2}<\gamma(\alpha) \eta$ の関係が 成立する. ただし, $\mathbf{z}:=\left[z^{T}, u_{e}^{T} \mathbf{R}^{1 / 2}, \xi^{T} \mathbf{S}^{1 / 2}\right]^{T}, u_{e}:=$ $u-\Gamma w, \gamma(\alpha):=(1-\alpha) \gamma_{0}+\alpha \gamma_{1}$ である.

補足 1 式(5)および (6)は, 線形システムが出カレ ギュレーションを達成するための条件を表す ${ }^{(9)}$.

本稿では, 定理 1 に基づき, 領域 $\mathcal{E}(P(1), \eta)$ を出 来るだけ広げるゲイン $F(1)=Y_{1} Q_{1}^{-1}$ および, 領域 $\mathcal{E}(P(0), \eta)$ 内で $z(t)$ の素早い収束を達成するゲイン $F(0)=Y_{0} Q_{0}^{-1}$ を設計する. これは， $\gamma_{0}, \gamma_{1}, \mathbf{R}, \mathbf{S}$ を適 切に設定することにより行われる. そして，得られた ゲインを $\alpha$ で補間し, 制御則 (10) を構成する.

\section{$3 \cdot 2$ オーバーシュートを抑制する制御アルゴリズ} ム 文献 ${ }^{(6)}$ では, 定理 1 に基づき設計された制御 器 (10) と, ある目標信号修正機構から構成される追従 制御アルゴリズムが提案された. この制御アルゴリズ

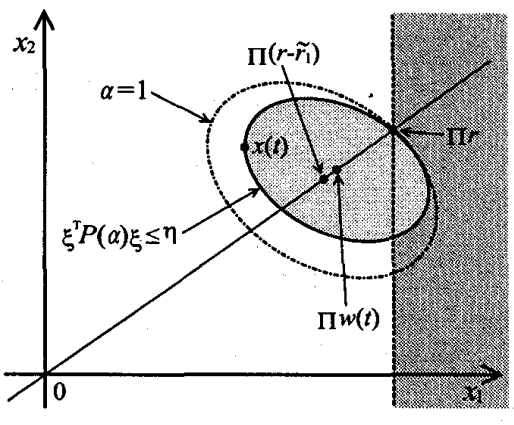

Fig. 4 Step 3 of Algorithm 1

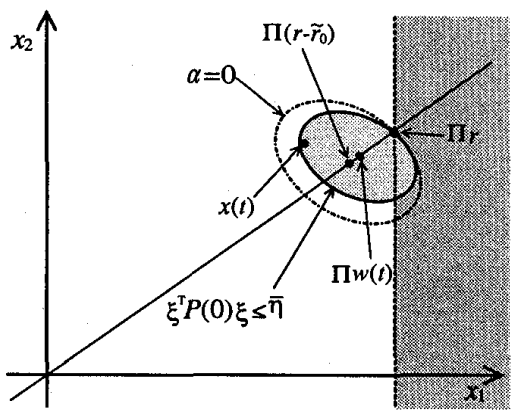

Fig. 5 Step 2 of Algorithm 1

ムを実行すると，制御量が目標值に近づくにつれて， フィードバックゲインがハイゲインとなり, 収束性が 改善される.また，外乱抑制性能も向上する(7)。 しか しながら, 文献 ${ }^{(6)}$ の制御アルゴリズムでは, 制御量の 過渡応答については特に考慮されていない. そのため, オーバーシュートがしばしば発生するといった問題が あった。これについては，次節以降の数值例および実 験結果で示す，そこで，本節では，オーバーシュート を抑制する新たな制御アルゴリズムを示す。ただし， ここでは，以下の仮定を設ける.

仮定 1 目標信号はスカラであるものとする。すなわ ち， $p=1$ であるものとする.

仮定 2 式 (5)，(6)について， $\Gamma=0$ を満たす解が存 在するものとする.

仮定 2 は，制御対象自身が積分特性を持つことを 意味する. 以下に，オーバーシュートを抑制する制御 アルゴリズムを示す，なお，アルゴリズム中の $\tilde{r}_{i}$ は， $\tilde{r}_{i}:=\left(\eta /\left(\Pi^{T} Q_{i}^{-1} \Pi I\right)\right)^{1 / 2}$ で定義される。 これを用いる と, $\mathcal{E}\left(Q_{i}^{-1}, \eta\right)$ の境界と, $\Pi$ 方向の直線との交点の座 標は $\Pi \tilde{r}_{i}$ と表せる (図 2 参照)。

\section{アルゴリズム 1}

Step 0: Set $t=0$

Step 1: Measure $x(t)$ and $r(t)$.

Step 2: If $x(t)-\Pi\left(r(t)-\tilde{r}_{0}\right) \in \mathcal{E}(P(0), \eta)$ or $x(t)-\Pi\left(r(t)+\tilde{r}_{0}\right) \in \mathcal{E}(P(0), \eta)$, find $\tilde{w}$ and 
$\bar{\eta}$ that satisfy

$$
\left\{\begin{array}{l}
(x(t)-\Pi \tilde{w})^{T} Q(0)^{-1}(x(t)-\Pi \tilde{w})=\bar{\eta} \\
(\Pi r(t)-\Pi \tilde{w})^{T} Q(0)^{-1}(\Pi r(t)-\Pi \tilde{w})=\bar{\eta}
\end{array}\right.
$$

Then, set $\alpha(t)=0, w(t)=\tilde{w}$ and go to Step 5.

Step 3: If $x(t)-\Pi\left(r(t)-\tilde{r}_{1}\right) \in \mathcal{E}(P(1), \eta)$ or $x(t)-\Pi\left(r(t)+\tilde{r}_{1}\right) \in \mathcal{E}(P(1), \eta)$, solve $\min _{\alpha \in[0,1], \tilde{w} \in \mathcal{R}^{p}} \alpha$, s.t.

$$
\left\{\begin{array}{l}
(x(t)-\Pi \tilde{w})^{T} Q(\alpha)^{-1}(x(t)-\Pi \tilde{w})=\eta \\
(\Pi r(t)-\Pi \tilde{w})^{T} Q(\alpha)^{-1}(\Pi r(t)-\Pi \tilde{w})=\eta
\end{array}\right.
$$

Then, set $\alpha(t)=\alpha, w(t)=\tilde{w}$ and go to Step 5.

Step 4: Solve $\min _{\tilde{w} \in \mathcal{R}^{p}}\|r(t)-\tilde{w}\|_{2}^{2}$, s.t.

$$
[x(t)-\Pi \tilde{w}]^{T} Q(1)^{-1}[x(t)-\Pi \tilde{w}] \leq \eta
$$

Step 5: Apply $u(t)=F(\alpha(t)) x(t)+M(\alpha(t)) w(t)$ to the system (1), (2).

Step 6: $t \leftarrow t+1$ and go to Step 1 .

以下では, アルゴリズム 1 の各ステップの目的につい て，簡単に説明を行う．アルゴリズム 1 を実行すると， 楕円集合 $\left\{x \in \mathcal{R}^{n}:[x-\Pi w(t)]^{T} P(\alpha(t))[x-\Pi w(t)] \leq\right.$ $\eta\}$ 内に状態量 $x(t)$ を閉じ込めた状態を保ちつつ，楕 円集合の中心 $\Pi w$ は目標状態 $\Pi r$ に徐々に近づく（図 3 参照）。このときの，各時刻における，棈円中心 $\Pi w$ の值が，アルゴリズム 1 の Step4 で算出される。そ の後，棈円集合の境界が $\Pi r$ に接すると，それ以降は， $\Pi r$ を棈円集合の境界上に含みながら，棈円集合は徐々 に収縮していく（図 4 参照）。このときの，各時刻に おける，棈円中心 $\Pi w$ の值および棈円の大きさを決定 するパラメータ $\alpha$ の值が, アルゴリズム 1 の Step3 で 算出される.さらに，アルゴリズム 1 の Step2 では， パラメータ $\alpha$ が零に収束して以降の棈円中心 $\Pi w$ の算 出が行われる（図 5 参照）。以上のプロセスを経るこ とにより，楕円集合がオーバーシュート発生領域（図 3〜5の灰色平面部）に大きく入り込むことを防ぐこ とができ，その結果，オーバーシュートを抑制するこ とが可能となる.

\section{3 可解性と漸近的追従性について アルゴリ} ズム 1 について以下が成り立つ.

定理 2 初期時刻 $t=0$ において $x(0)-\Pi \tilde{w} \epsilon$ $\mathcal{E}(P(1), \eta)$ を満たす $\tilde{w}$ が存在するものとする.この とき，全ての時刻でアルゴリズム 1 は可解であり， $r(t)=\bar{r}, \forall t \geq T_{r}$ のとき, $\lim _{t \rightarrow \infty} w(t)=\bar{r}$ およ び $\lim _{t \rightarrow \infty} z(t)=0$ が成り立つ.
証明）はじめに，可解性が全時刻で成り立つことを示 す. 仮定より, $x(0)-\Pi \tilde{w} \in \mathcal{E}(P(1), \eta)$ を満たす $\tilde{w}$ が 存在するので, 時刻 $t=0$ においては, 少なくとも, Step4の最適化問題に対する解 $\alpha(0), w(0)$ は必ず存在 する. Step2 あるいはStep3 の判定条件を満たす領域 に $x(0)$ が属している場合には，それぞれの等式制約を 満たす解 $\alpha(0), w(0)$ が存在する.このようにして得ら れた制御入力 $u(0)=F(\alpha(0)) x(0)+M(\alpha(0)) w(0)$ を 制御対象に加えると, 次の時刻 $t=1$ における状態量 $x(1)$ は $x(1)-\Pi w(0) \in \mathcal{E}(P(\alpha(0)), \eta \kappa), \kappa<1$ を満た す (文献 ${ }^{(6)}$ の定理 1 参照)。これより, 時刻 $t=1$ に おいても，少なくとも，Step4の最適化問題に対する 解 $\alpha(1), w(1)$ は必ず存在する. Step2 あるいは Step3 の判定条件を満たす領域に $x(1)$ が属している場合に は，それぞれの等式制約を満たす解 $\alpha(1), w(1)$ が存在 する. したがって, 時刻 $t=1$ においても解の存在性 が保証される. 同様の議論は $t \geq 2$ においても成り立 つ. よって, アルゴリズム 1 の可解性は全時刻で保証 される。

つぎに, $r(t)=\bar{r}, \forall t \geq T_{r}$ となる場合に， $\lim _{t \rightarrow \infty} w(t)=\bar{r}$ および $\lim _{t \rightarrow \infty} z(t)=0$ が成り立つ ことを示す．ある時刻 $t$ において Step4 の判定条件を 満たす領域に $x(t)$ が属しているものとする.このとき， Step 4 の最適化問題が解かれ，修正目標信号 $w(t)$ が計 算される. また， $\alpha(t)=1$ と選ばれる.このようにして 得られた制御入力 $u(t)=F(\alpha(t)) x(t)+M(\alpha(t)) w(t)$ を制御対象に加えると, 状態量 $x(t+1)$ は $x(t+1)-$ $\Pi w(t) \in \mathcal{E}(P(\alpha(t)), \eta \tilde{\kappa}), \tilde{\kappa}<1$ を満たす (文献 ${ }^{(6)}$ の定 理 1 参照). $x(t+1)$ が Step2 あるいはStep3の判定条 件を満たさない場合, Step4の最適化問題が解かれる. このとき, $x(t+1)-\Pi w(t) \in \mathcal{E}(P(\alpha(t)), \eta \tilde{\kappa}), \tilde{\kappa}<1$ なので, $\|\Pi \bar{r}-\Pi w(t)\|_{2}$ が減少するように $w(t)$ を選 ぶことが可能である.よって，このプロセスを繰り返 すことで, 1) $w(t)$ は $\bar{r} に, x(t)$ は $\Pi \bar{r}$ に収束するか, 2) $x(t)$ は Step3 の判定条件を満たす領域（図 3 の点 線棈円の内部）に到達する.

ある時刻 $t に ，$ Step3 の判定条件を満たす領域に $x(t)$ が到達した場合, Step3 の最適化問題が解かれ， $\alpha(t), w(t)$ が計算される。これらを用いて制御入力を 構成し, 制御対象に加えると, Step4の場合と同様に, $x(t+1)-\Pi w(t) \in \mathcal{E}(P(\alpha(t)), \eta \bar{\kappa}), \bar{\kappa}<1$ が成り立 つ.これより，時刻 $t+1$ における Step3 の最適化問 題の解は, $\|\Pi \bar{r}-\Pi w(t)\|_{2}$ が減少するように選ばれる （図 4 参照）。ここのプロセスを繰り返すことで，ある 時刻で $x(t)$ はStep2 の判定条件を満たす領域に到達 する. Step2 の判定条件を満たす領域に $x(t)$ が到達 


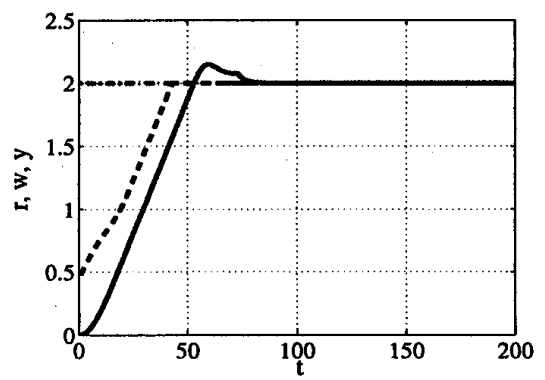

Fig. $6 r(t)$ (dash-dot), $w(t)$ (dashed), $y(t)$ (solid)

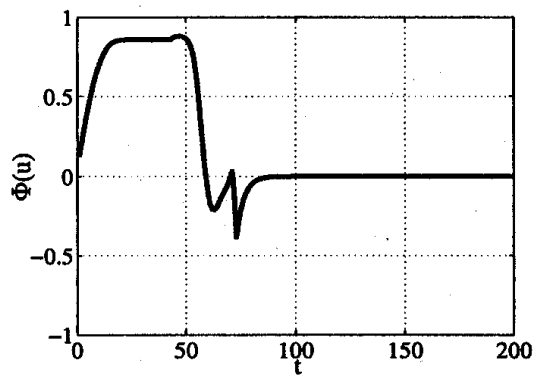

Fig. $7 \quad \Phi(u(t))$

すると, Step3 の場合と同様の議論により, $w(t)$ は $\vec{r}$ に， $x(t)$ は $\Pi \bar{r}$ に収束する（図 5 参照）。その結果, $\xi(t)$ は零に収束する. 一方, $\Gamma=0$ なので, 式 $(10)$ よ り, $u=F(\alpha) \xi$ である. この関係と, 式 $(6),(2)$ より, $z=C \xi+D \Phi(F(\alpha) \xi)$ の関係が得られる. したがって, $t \rightarrow \infty$ で $z(t) \rightarrow 0$ が成り立つ.

3.4 求解アルゴリズムアルゴリズム 1 を実行 するためには，いくつかの等式および最適化問題を毎 時刻解くことが必要となる. 以下では，これらを効率 的に解く方法を示す.

3.4.1 Step2の等式の解法 Step 2 の式 (11)の 解は以下で与えられる.

$$
\tilde{w}=\frac{x^{T} Q_{0}^{-1} x-\Pi^{T} Q_{0}^{-1} \Pi r^{2}}{2\left(x^{T} Q_{0}^{-1} \Pi-\Pi^{T} Q_{0}^{-1} \Pi r\right)}
$$

3.4.2 Step4の最適化問題の解法 Step 4 の最 適化問題の解 $\tilde{w}$ は,

$$
w_{1}=\frac{-b+\sqrt{b^{2}-a c}}{a}, w_{2}=\frac{-b-\sqrt{b^{2}-a c}}{a}
$$

のうち, $\left\|r(t)-w_{i}\right\|_{2}^{2}$ がより小さな值を与える $w_{i}$ として決定できる.ただし $, a:=\Pi^{T} Q^{-1} \Pi, b:=$ $x^{T} Q^{-1} \Pi, c:=x^{T} Q^{-1} x-\eta$ である.

\subsubsection{Step3 の最適化問題の解法 Step 3 の最} 適化問題の解を得ることは一般に困難である. そこで, ここでは，この最適化問題の近似解を効率よく算出す る方法を示す.ただし，ここでは， $x(t)-\Pi\left(r(t)-\tilde{r}_{1}\right) \in$

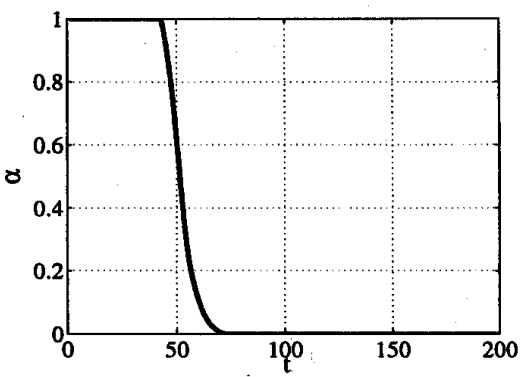

Fig. $8 \alpha(t)$

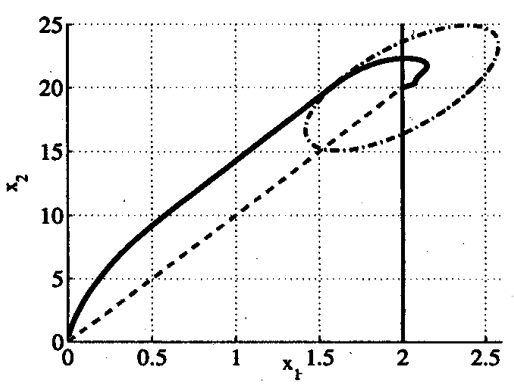

Fig. 9 State trajectory

$\mathcal{E}(P(1), \eta)$ が成り立つ場合について説明する，以下に, 具体的な計算アルゴリズムを示す.

\section{アルゴリズム 2}

Step 0: Set an integer $N_{\alpha}>0$ and $L_{N}=0$

Step 1: $\alpha=L_{N} / N_{\alpha}$

Step 2: $Q(\alpha)=(1-\alpha) Q_{0}+\alpha Q_{1}$

Step 3: $P(\alpha)=Q(\alpha)^{-1}$

Step 4: $\tilde{r}=\left(\eta /\left(\Pi^{T} P(\alpha) \Pi\right)\right)^{1 / 2}$

Step 5: If $[x(t)-\Pi(r(t)-\tilde{r})]^{T} P(\alpha)[x(t)-\Pi(r(t)-$ $\tilde{r})] \leq \eta$, go to Step 7 .

Step 6: $L_{N} \rightarrow L_{N}+1$ and go to Step 1 .

Step 7: Set $\alpha(t)=\alpha$ and $w(t)=r(t)-\tilde{r}$.

上記アルゴリズム中， $N_{\alpha}$ は $\alpha$ 分割数を表す.こ の計算を実行すると, $\Pi(r(t)-\tilde{r})$ を中心とする楕円集 合 $[x-\Pi(r(t)-\tilde{r})]^{T} P(\alpha)[x-\Pi(r(t)-\tilde{r})] \leq \eta$ (図 4 の灰色の楕円集合）内部に $x(t)$ が含まれるまで, 楕円 集合の拡大が行われる. そして，楕円集合内部に $x(t)$ が含まれた時点での $\alpha$ と $r(t)-\tilde{r}$ が，それぞれ，アル ゴリズム 1 の Step3 の解 $\alpha(t)$ および $\tilde{w}$ として用いら れる. なお， $x(t)-\Pi\left(r(t)-\tilde{r}_{1}\right) \in \mathcal{E}(P(1), \eta)$ が成り 立つ場合には，アルゴリズム 2 のを $\tilde{r}$ をに全て置き 換え，同様の計算を行うことにする.

補足 2 Step 3 の最適化問題を近似的に解くもう一つ の方法として，式 (12) の等式を，

$$
\left\{\begin{array}{l}
(x(t)-\Pi \tilde{w})^{T} Q(\alpha)^{-1}(x(t)-\Pi \tilde{w}) \leq \eta \\
(\Pi r(t)-\Pi \tilde{w})^{T} Q(\alpha)^{-1}(\Pi r(t)-\Pi \tilde{w}) \leq \eta
\end{array}\right.
$$




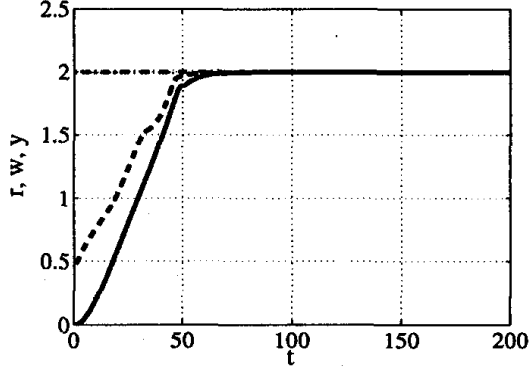

Fig. $10 r(t)$ (dash-dot), $w(t)$ (dashed), $y(t)$ (solid)

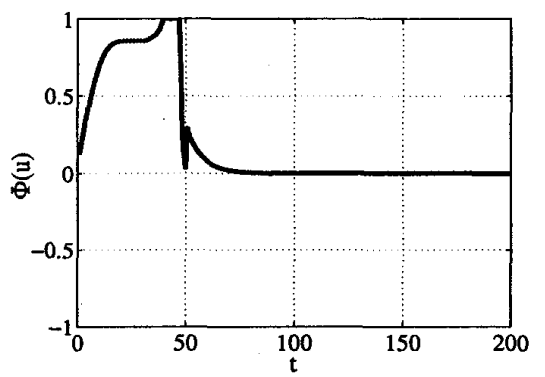

Fig. $11 \Phi(u(t))$

に置き換える方法が考えられる。これらの不等式は, Schur Complement ${ }^{(10)}$ を適用することで， $\alpha$ と $\tilde{w}$ に 関する $L M I$ 条件に帰着出来る。したがって，この場 合, 結果として得られる最適化問題は, $L M I$ 最適化問 題となる. なお, この場合, $x(t)$ の值によっては, 棈 円集合が，オーバーシュート発生領域内に大きく入り 込む可能性がある。

\section{4. 数 值 例}

以下のシステムについて考える。

$$
\begin{aligned}
x_{p}(t+1) & =x_{p}(t)+0.05 \Phi(u(t)) \\
y(t) & =x_{p}(t) \\
x_{c}(t+1) & =x_{c}(t)+z(t) \\
z(t) & =w(t)-y(t)
\end{aligned}
$$

ここで, $x_{p}, u, y \in \mathcal{R}$ は，それぞれ, 制御対象の状 態量, 制御入力, 制御量である. また, $x_{c}, w, z \in \mathcal{R}$ は，それぞれ，制御器の状態量，修正目標信号，追従 誤差を表す。このシステムは, 状態量を $x=\left[x_{p}, x_{c}\right]^{T}$ と選び, さらに係数行列を

$$
A=\left[\begin{array}{cc}
1 & 0 \\
-1 & 1
\end{array}\right], B=\left[\begin{array}{c}
0.05 \\
0
\end{array}\right], E=\left[\begin{array}{l}
0 \\
1
\end{array}\right]
$$

$C=[-1,0], D=0, D_{w}=1$ と選ぶことで, 式 (1), (2) の形式に帰着できる.

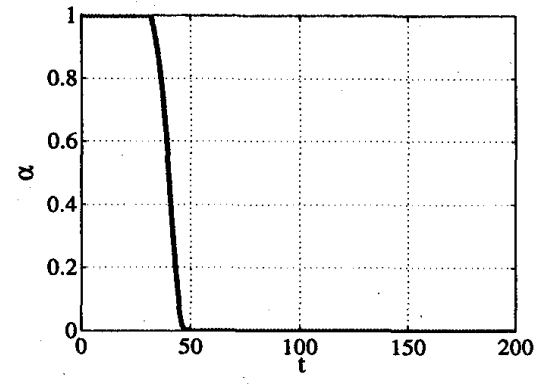

Fig. $12 \alpha(t)$

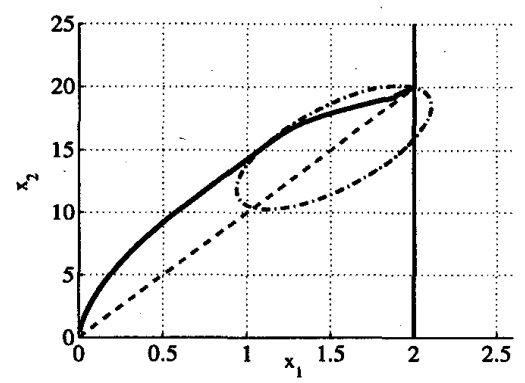

Fig. 13 State trajectory

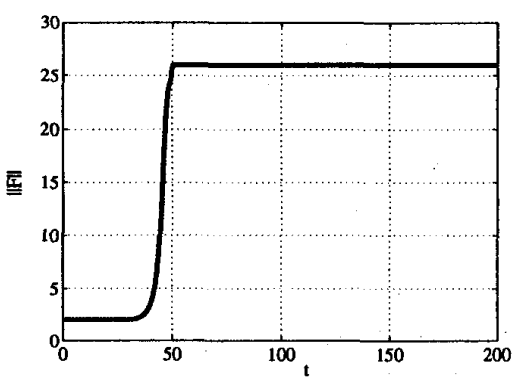

Fig. $14 \quad\|F(\alpha)\|$

このシステムについて，式 (5)，(6) を解いたところ， $\Pi=\left[1, \Pi_{2}\right]^{T}, \Gamma=0$ が得られた. ここで, $\Pi_{2}$ は任 意定数であり，ここでは， $\Pi_{2}=10$ と選ぶことにす る. さらに, $\gamma_{0}=40, \gamma_{1}=51412, R=10^{-6}, \mathbf{S}=$ $5 \times 10^{2} I, \eta=1, \mathbf{E}_{1}=1, \mathbf{E}_{2}=0$ として定理 1 の LMI 条件 ${ }^{(10)}$ を満たす解を求めたところ,

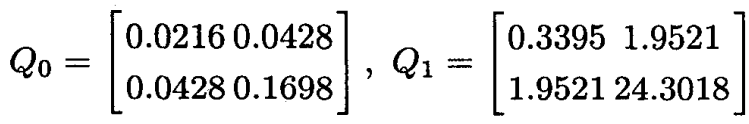

$Y_{0}=\left[\begin{array}{lll}-0.3283, & -0.2107\end{array}\right], \quad Y_{1}=$ $[-0.3410,0.3180], Z_{0}=[-0.1049,-0.0460], Z_{1}=$ $[-0.3410,0.3180]$ を得た。このとき, $\alpha=0$ および $\alpha=1$ でのフィードバックゲインの 值は, $F(0)=[-25.4054,5.1662], \quad F(1)=$ $[-2.0060,0.1742], M(0)=-26.2571, M(1)=$ 0.2638 となる。

まず，図6〜図 9 に，文献 ${ }^{(6)}$ の制御アルゴリズムを 


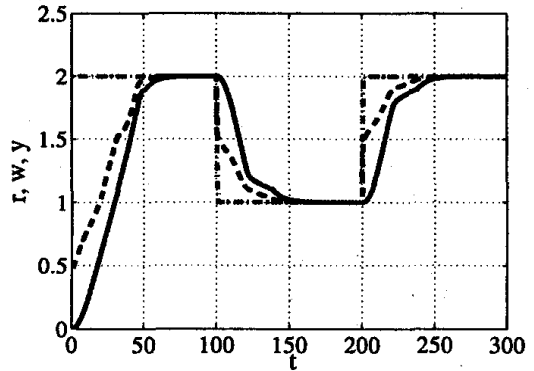

Fig. $15 \quad r(t)$ (dash-dot), $w(t)$ (dashed), $y(t)$ (solid)

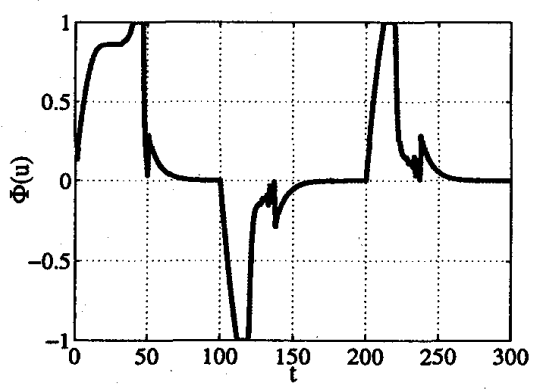

Fig. $16 \quad \Phi(u(t))$

用いた場合の数値シミュレーション結果を示す、ただ し, $r(t)=2, \forall t \geq 0$ である. $y(t)$ は目標值 $r(t)$ に漸 近的に追従しているものの, オーバーシュートが生じ ていることを確認出来る。これは, 文献 ${ }^{(6)}$ の制御アル ゴリズムでは， $\alpha=1$ の棈円集合（図 9 の一点鎖線） の中心 $\Pi w(t)$ が $\Pi r$ に一致した後， $\alpha$ の縮小が行われ るため，楕円集合がオーバーシュート発生領域（本例 題の場合, 図 9 中の $y=x_{1} \geq r=2$ の領域）に大き く入り込むためである.

つぎに，図 10〜14に，本稿で提案するアルゴリズ ム 1 を適用した結果を示す。なお,フィードバック制 御器を構成する行列 $Q_{i}, Y_{i}$ は上記のものを用いた。 ま た, $\alpha$ の分割数は, $N_{\alpha}=1000$ とした. 図 13 より 明らかなように棈円集合がオーバーシュート発生領域 $\left(x_{1} \geq 2\right)$ 内に入ることが抑えられている. その結果, 図 10 より明らかなように，オーバーシュートが抑制 されている. 図 14 は, 各時刻における, フィードバッ クゲイン $F(\alpha)$ の最大特異值を描いたものである.こ れより, 制御量が目標值に近づくにつれてハイゲイン となっていることが確認出来る.

図 15〜17に, 目標信号 $r(t)$ を矩形に切り替えた場 合のシミュレーション結果を示す。この場合にも, 制 御量 $y(t)$ はオーバーシュートを生じることなく目標值 に収束している.

なお，本数值シミュレーションは, Intel Core2 2.33

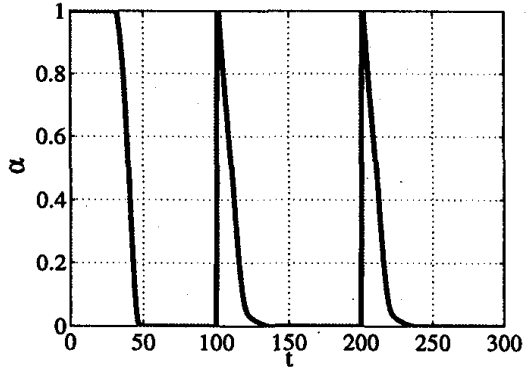

Fig. $17 \alpha(t)$

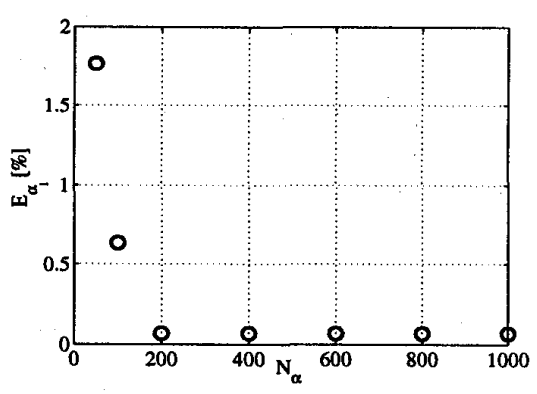

Fig. $18 E_{\alpha_{i}}$

$\mathrm{GHz}$ 1GB RAM のコンピュータ上で, MATLAB を 用いて実行した。この場合，1サンプルあたりの最大 計算時間は $0.0735 \mathrm{~s}$ であった。この計算時間は， $N_{\alpha}$ をより小さな值に設定することで短縮可能である．例 えば, $N_{\alpha}=200$ に設定した場合，1サンプルあたり の最大計算時間は $0.0249 \mathrm{~s}$ であった。 なお， Step3の 最適化問題を, 補足 2 の方法により LMI 最適化問題 として解いた場合，1サンプルあたりの最大計算時間 は $1.3480 \mathrm{~s}$ であった. ただし，このとき，LMI 最適化 問題は, Matlab/Robust Control Toolboxを用いて解 いた.

なお，本数值シミュレーションでは，アルゴリズ ム 1 のStep3 を解く際, アルゴリズム 2 を用い近似 的に解いた。 以下では，アルゴリズム 2 の近似精度 について検討する.ただし，ここでは， $\alpha$ の分割数 を $N_{\alpha}=10000$ と十分大きな值に設定した場合に得 られる $\alpha$ の值（これを $\alpha_{10000}$ と表すことにする）を 厳密解と考えることにし，この值と，より小さな $N_{\alpha}$ について得られる $\alpha$ の值を比較することで, 近似精 度について検討する，なお，アルゴリズム 2 では， 分割数が大きいほど, 解の精度が向上するものと期 待出来る。 $N_{\alpha}$ を $50,100,200,400,600,800,1000$ と設定した場合に得られる解を，それぞ れ , $\alpha_{50}, \alpha_{100}, \alpha_{200}, \alpha_{400}, \alpha_{600}, \alpha_{800}, \alpha_{1000}$ と 表すことにする.またここでは，誤差は， $E_{\alpha_{i}}:=\left(\alpha_{i}-\alpha_{10000}\right) / \alpha_{10000} \times 100[\%]$ で評価す 


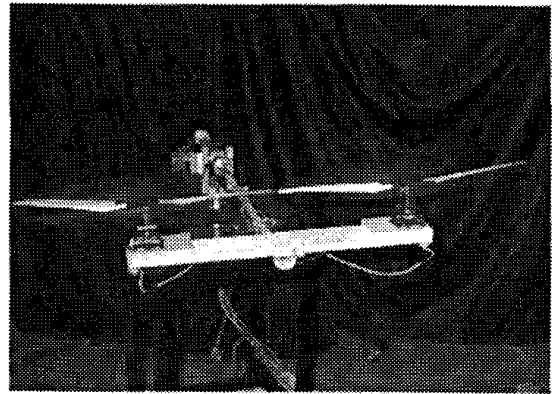

Fig. 19 Twin-rotor helicopter model

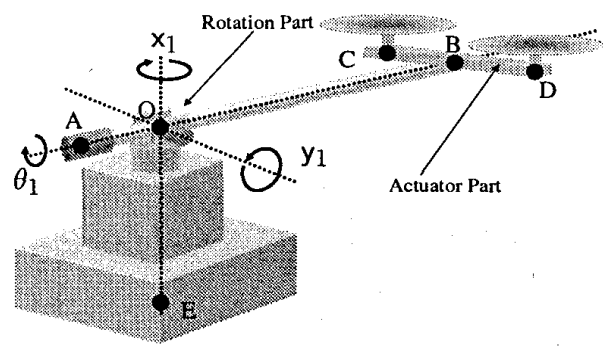

Fig. 20 Experimental apparatus of the twin-rotor helicopter system

ることにした．図 18 に， $E_{\alpha_{i}}$ と $N_{\alpha}$ の関係を示す，た だし，ここでは， $x=[1,12]^{T}$ と選んだ. 図 18 より， 分割数 $N_{\alpha}$ を 200 以上に設定すると， $E_{\alpha_{i}}$ は $0.1 \%$ 以 下となることが確認出来る. 以上より，分割数 $N_{\alpha}$ を 数百以上の值に設定しておけば，十分高い精度で近 似計算を行えるものと期待出来ることが確認出来る.

\section{5． 実機実験による有効性の検証}

本節では，前節の手法に基づき，ツインローターへ リコプターモデル (8) (図 19）に対する目標信号追従 制御器を設計し，その有効性を実験的に検証する.

$5 \cdot 1$ 数式モデル 図 20 に示すように, ツイン ローターヘリコプターモデルは $\mathrm{x}_{1}, \mathrm{y}_{1}, \theta_{1}$ 軸回りの 3 自由度を持ち，機体（図 20 中の Actuator Part）の 両端には推力を制御出来るローターが設置されてい る. 状態変数を $x_{p}:=\left[\mathrm{v}_{x}, \mathrm{y}_{1}, \mathrm{y}_{2}, \theta_{1}, \theta_{2}\right]^{T}$, ただし, $\mathrm{v}_{x}:=\dot{\mathrm{x}}_{1}, \mathrm{y}_{2}:=\dot{\mathrm{y}}_{1}, \theta_{2}:=\dot{\theta}_{1}$ と選ぶことにする. 重力 項を補償した後, このへリコプターモデルのダイナミ クスを $x_{p}=0$ 近傍で近似線形化すると，以下の線形 ダイナミカルモデルが得られる ${ }^{(7)}$.

$$
x_{p}(t+1)=A_{p} x_{p}(t)+B_{p} \Phi(u(t))
$$

ここで, $u \in \mathcal{R}^{2}$ は, Actuator Part の両端に設けら れたローターが発生する推力に対応する無次元量で ある(7). $A_{p}:=\exp \left(A_{c} T\right), B_{p}:=B_{d} \Xi(0) f_{\max }$ であ
り, $B_{d}:=\int_{0}^{T} \exp \left(A_{c} \tau\right) d \tau B_{c}$ である.また, $A_{c}:=$ $\partial \mathbb{F} /\left.\partial x_{p}\right|_{x_{p}=0}, B_{c}:=\mathbb{G}(0), \Xi\left(x_{p}\right):=\Xi_{1}\left(x_{p}\right) \Xi_{2}$ で あり,

$$
\mathbb{F}\left(x_{p}\right):=\left[\begin{array}{c}
\frac{L_{1}}{L_{2}} M g \tan \theta_{1} \cos \mathrm{y}_{1}-L_{4} \mathrm{\times}_{2} \\
\mathrm{y}_{2} \\
0 \\
\theta_{2} \\
-\sin \theta_{1} \cos \theta_{1}\left(\mathrm{v}_{x}^{2}-\mathrm{y}_{2}^{2}\right)
\end{array}\right],
$$

$$
\begin{aligned}
& \mathbb{G}\left(x_{p}\right):=\left[\begin{array}{cc}
L_{1} \tan \theta_{1} & 0 \\
0 & 0 \\
L_{2} & 0 \\
0 & 0 \\
0 & L_{3}
\end{array}\right], \\
& \Xi_{1}\left(x_{p}\right):=\left[\begin{array}{cc}
\cos \theta_{1} & 0 \\
0 & 1
\end{array}\right], \Xi_{2}:=\left[\begin{array}{cc}
1 & 1 \\
l_{r} & -l_{r}
\end{array}\right]
\end{aligned}
$$

である.また，

$$
\begin{aligned}
L_{1} & :=\frac{2 l_{a}}{m_{a} l_{a}^{2}+m_{b} l_{b}^{2}+4 \bar{m} l_{a}^{2}+I_{a}+I_{b}+\bar{m} l_{r}^{2}} \\
L_{2} & :=\frac{2 l_{a}}{m_{a} l_{a}^{2}+m_{b} l_{b}^{2}+4 \bar{m} l_{a}^{2}+I_{a}+I_{b}} \\
L_{3} & :=\frac{1}{\bar{m} l_{r}^{2}} \\
M & :=\frac{m_{a} l_{a}+2 \bar{m} l_{a}-m_{b} l_{b}}{m_{a} l_{a}^{2}+m_{b} l_{b}^{2}+4 \bar{m} l_{a}^{2}+I_{a}+I_{b}}
\end{aligned}
$$

である.

ただし，上記のモデルは，文献 ${ }^{(8)}{ }^{(7)}$ のデルに対 し, $\mathrm{x}_{1}$ 軸周りの粘性抵抗成分 $-L_{4} \mathrm{x}_{2}$ を $\mathbb{F}\left(x_{p}\right)$ に加 えている，なお，実験装置の各物理パラメータの值 は, $m_{a}=0.325[\mathrm{~kg}], m_{b}=0.52[\mathrm{~kg}], \bar{m}=0.158[\mathrm{~kg}]$, $I_{a}=0.0715\left[\mathrm{kgm}^{2}\right], \quad I_{b}=0.04\left[\mathrm{kgm}^{2}\right], \quad l_{a}=0.43[\mathrm{~m}]$, $l_{b}=0.24[\mathrm{~m}], \quad l_{r}=0.188[\mathrm{~m}], v_{\max }=5.5[\mathrm{~V}], a_{1}=$ $0.2729[\mathrm{~N} / \mathrm{V}], a_{2}=0.2846[\mathrm{~N} / \mathrm{V}], L_{4}=0.5\left[\mathrm{~s}^{-1}\right]$ であ る.これらは予備実験により求めた.

また，ここでは, 機体水平方向の角速度 $v_{x}$ の追 従制御問題について考えるので, 制御量は $y(t)=$ $C_{p} x_{p}(t)$, 評価出力は $z:=y-w$ とする. ただし, $C_{p}=[1,0,0,0,0]$ である.

$5 \cdot 2$ 目標信号追従制御器の設計 前節で示した ツインローター浮上系の数式モデルについて，ロー ター推力の制限の下で，機体の垂直方向変位および姿 勢角を安定化し，かつ，機体水平方向角速度 $v_{x}$ を目 標速度へ追従させる制御問題について考える．実機で は，軸受け部の摩擦や空気抵抗など，モデル化の困難 な外乱が存在し，これらは目標值への追従性能を劣化 


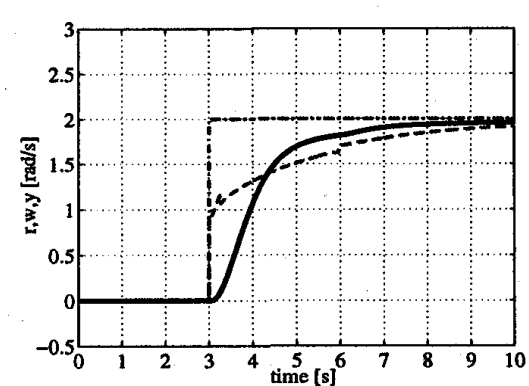

Fig. $21 \quad r(t)$ (dash-dot), $w(t)$ (dashed), $y(t)$ (solid)

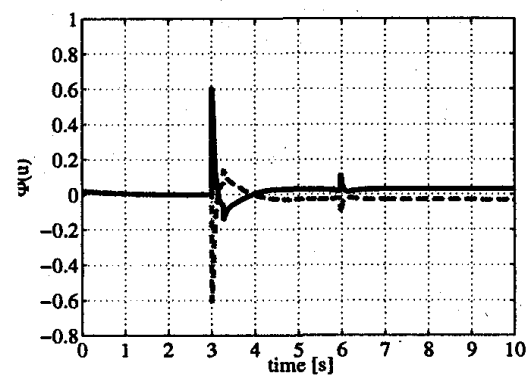

Fig. $22 \Phi(u(t))$

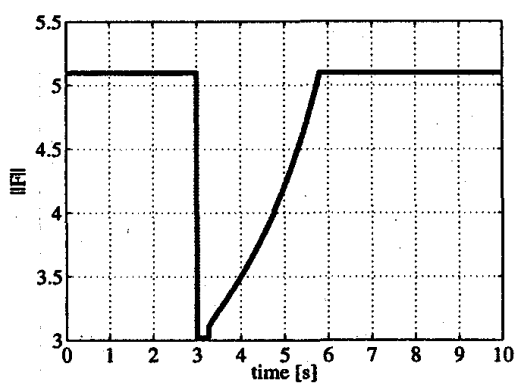

Fig. $23\|F(\alpha)\|$

させる原因となる.そこで,ここでは,

$$
\begin{array}{r}
x_{c}(t+1)=x_{c}(t)+e(t) \\
e(t)=w(t)-y(t)
\end{array}
$$

で表される積分補償を含む制御器を用いることにする. システム (21)-(23) は, 状態量を $x=\left[x_{p}^{T}, x_{c}\right]^{T}$ と選 び,さらに, 係数行列を

$$
A=\left[\begin{array}{cc}
A_{p} & 0 \\
-C_{p} & 1
\end{array}\right], B=\left[\begin{array}{c}
B_{p} \\
0
\end{array}\right], E=\left[\begin{array}{l}
0 \\
1
\end{array}\right]
$$

$C=\left[C_{p}, 0\right], D=0, D_{w}=-1$ と選ぶことで, 式 (1)，(2) の形式に書き直せる.このようにして得 られたシステムについて, 式 (5)，(6) を解いたとこ ろ, $\Pi=[1,0,0.1095,0,0]^{T}, \Gamma=0$ が得られた.さ らに, $\gamma_{0}=5000, \gamma_{1}=40000, \mathbf{R}=150 I, \mathbf{S}=$

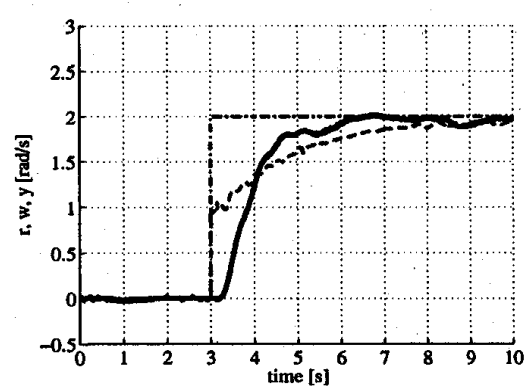

Fig. $24 \quad r(t)$ (dash-dot), $w(t)$ (dashed), $y(t)$ (solid)

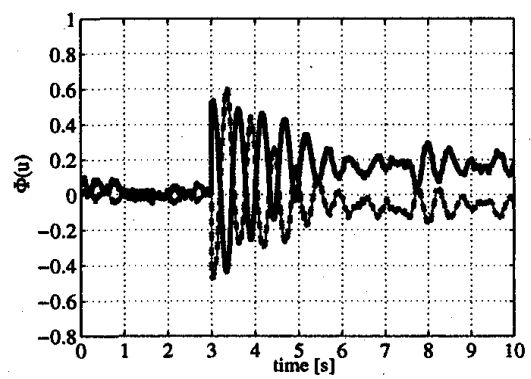

Fig. $25 \quad \Phi(u(t))$

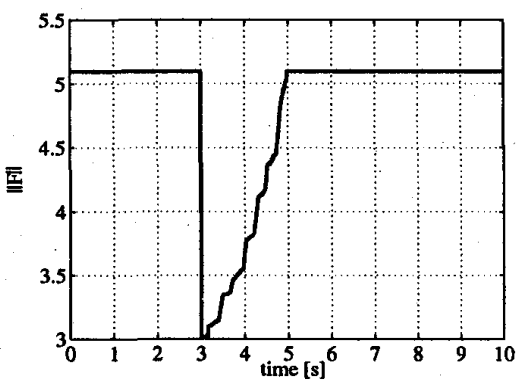

Fig. $26\|F(\alpha)\|$

$\operatorname{diag}[100,50,1,500,200,0.001,0.00001], \quad \eta=1$ とし て定理 1 の LMI 条件を満たす解 $Q_{i}, Y_{i}, Z_{i}$ を求めた.

$5 \cdot 3$ 実験結果 目標信号を $r(t)=2 \mathrm{rad} / \mathrm{s}, \forall t \geq$ 3s として実験を行った. ただし, サンプル周期は $T=$ $5 \mathrm{~ms}$ とし，また， $\alpha$ の分割数は $N_{\alpha}=500$ とした。 ま ず, 図 21-23に，アルゴリズム 1 を用い, 数值シミュ レーションを行った結果を示す.つぎに，図 24-26に， アルゴリズム 1 を用い, 実機実験を行った結果を示す. 数值シミュレーションの結果, 実験結果とも, 制御量 $y$ はオーバーシュートを生じることなく，目標值 $r$ 人追 従していることが確認出来る. また, 数值シミュレー ションの結果と実験結果を比較すると, 実験結果にお いて制御入力の応答（図 25）が振動的になっている 以外は，比較的良好な一致を示している．実験結果に 見られる制御入力の振動的振る舞いは，制御系設計時 


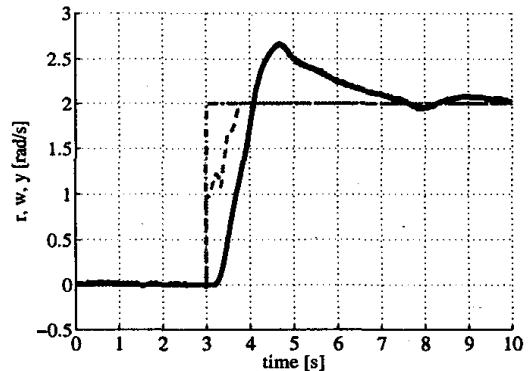

Fig. $27 \quad r(t)$ (dash-dot), $w(t)$ (dashed), $y(t)$ (solid)

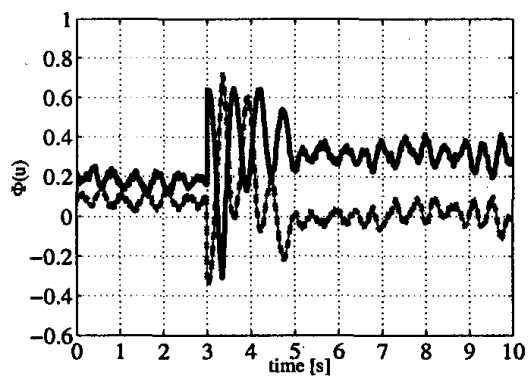

Fig. $28 \quad \Phi(u(t))$

に無視したアクチュエータのダイナミクスや同定誤差 等のモデル化誤差によるものと考えられる.また，こ のような制御入力の振動的振る舞いのため, よりハイ ゲインなフィードバック制御器を用いることは困難で あった。

つぎに，文献 ${ }^{(6)}$ のルゴリズムを用いた場合の実験 結果を図 27 , 図 28 に示す. 文献 ${ }^{(6)}$ のアルゴリズムを 用いた場合，大きなオーバーシュートが生じているこ とが確認出来る.このオーバーシュートは, 前節の数 值例の場合と同様, 修正目標信号 $w$ の計算方法に起 因して生じている.

なお,アルゴリズム 1 を実行する際，各サンプル 時刻において，制御入力を算出するのに要した計算時 間は，最大 $0.77 \mathrm{~ms}$ ，平均 $0.16 \mathrm{~ms}$ であった。ただし， 実装時に用いたコンピュータはIntel Core2 3.00GHz, 2GB RAM であり，Matlab/xPC-Target を用いて計 算アルゴリズムを実装した.

\section{6.おわりに}

本稿では, 入力拘束を有する離散時間システムに対 する目標信号への追従制御則の一構成法を示した. 本 稿の制御則は状態に依存した可変ら゙インフィードバッ ク制御則と目標信号修正機構から構成されている. 提 案制御アルゴリズムでは，アルゴリズムの可解性が保 証される範囲内で, 出来るだけ元の目標信号に近い值
を持つ修正目標信号が算出される．このとき，修正目 標信号および可変ゲインの值に関する自由度を利用す ることで，制御量のオーバーシュートを抑制する方法 を示した．提案制御アルゴリズムを実装するためには， 実時間でいくつかの等式制約および最適化問題を解く ことが必要となるが，これを効率的に解く手法を示し た.さらに, 提案制御手法の有効性を, 数值例および 実験例により示した。

\section{文献}

(1) Hu,T. and Lin,Z., "Control Systems with Actuator Saturation: Analysis and Design", Springer (2001)

(2) Pachter,M. and Miller,R.B., "Manual Flight Control with Saturating Actuators", IEEE Control Systems Magazine, February, (1998)

(3) Allgöwer, F. and Zhen,A. (Eds.), "Nonlinear Model Predictive Control," Birkhäuser, (2000)

(4) Kogiso,K. and Hirata,K., "Static Controller Switching Approach to Constraint Fulfillment for Timevarying References and Its Experimental Validations", Trans. JSME, C-73-726, (2007), pp.422-427

(5) Wada,N. and Saeki,M., "An LMI Based Scheduling Algorithm for Constrained Stabilization Problems", Systems \& Control Letters, 57-3, (2008), pp.255-261

(6) Wada,N., Minami,M. and Saeki,M., "Tracking Control of Input Constrained Discrete-Time Systems-A Method Based on State-Dependent Gain-Scheduling and Reference Management-", Trans. JSME, C-74743, (2008), pp.1725-1733

(7) Wada,N., Minami,M. and Saeki,M., "Tracking Control of a Twin-Rotor Helicopter Model with Actuator Constraints", Journal of the Robotics Society of Japan, 27-2, (2009), pp.199-208

(8) Imura,J., Ieki,K., Saeki,M. and Wada,Y., "Experiments of Twin-Rotor Helicopter model using Exact Linearization via Dynamic State Feedback," Trans. JSME, C-66-648, (2000), pp.2630-2637

(9) Francis,B.A., "The linear multivariable regulator problem", SIAM J. Control \& Optimization, 15, (1975), pp.480-505

(10) Boyd,S., Ghaoui,L.E., Feron,E. and Balakrishnan,V., "Linear Matrix Inequalities in System and Control Theory", SIAM, (1994) 